\title{
OSNIVANJE I RAD KRIŽARSKE ORGANIZACIJE U HRVATSKOJ (1930. - 1945.)
}

\author{
Zdravko Matić - Damir Stručić
}

Sveučilište u Zagrebu

Hrvatsko vojno učilište „Dr. Franjo Tuđman“ zdravko.matic71@gmail.com

dastrucic@yahoo.com
UDK: 272-662:3(497.5)“1930/1945“

https://doi.org/10.34075/cs.55.2.6

Izvorni znanstveni rad Rad zaprimljen 9/2019.

\section{Sažetak}

Nakon uvođenja Šestosiječanjske diktature 1926. i zabrane rada Hrvatskog orlouskog saveza, već je 1930. osnovana Križarska organizacija kako bi se ponouno sakupila raspršena hrvatska katolička mladež koja je bila organizirana u orlovstvu i koja je bila teško pogođena ukidanjem svoje Orlouske organizacije. Nova Križarska organizacija temeljila se na načelima međunarodne organizacije Apostolata molitve, i to njezina ogranka za mladež koji se u Francuskoj nazivao „Croisade Eucharistique“. Jedino je pod tim uvjetom nova organizacija mogla biti priznata od beogradskog režima, ali ipak uz mnoge teškoće, koje su postupno bile nadvladane. Po želji zagrebačkog nadbiskupa koadjutora Alojzija Stepinca 1936. g. Križarska organizacija postaje dio Katoličke akcije i djeluje u skladu s njezinim pravilima, ali je zadržala svoje ime i duhovnu baštinu naslijeđenu od dokinute Orlovske organizacije. Križarska organizacija bila je u svojim društvima prisutna u svim hrvatskim biskupijama i bila je najbrojnija katolička organizacija za mladež u to vrijeme. U njoj su tisuće mladića i djevojaka primali solidan katolički odgoj i formirali se za vjerne članove Katoličke Crkve, njezine suradnike i apostole. Da bi zaštitio članstvo od komunističkih progona, nadbiskup Alojzije Stepinac raspustio je u srpnju 1945. g. sve organizacije Katoličke akcije, među kojima je bila i Križarska organizacija.

Ključne riječi: orlovstvo, križarstvo, katoličke organizacije, vodstvo, Propulipac, Stepinac, progoni

\section{1. ŠESTOSIJEČANJSKA DIKTATURA I ZABRANA RADA HRVATSKOG ORLOVSKOG SAVEZA}

Šestog siječnja 1929. kralj Aleksandar Karađorđević posve je neočekivano za široku javnost objavio manifest kojim je ukinuo Vidovdanski ustav te raspustio Narodnu skupštinu i zabranio rad 
svim strankama s nacionalnim, vjerskim ili regionalnim obilježjima. Donio je ukaz o sastavljanju nove vlade, na čelu s generalom Petrom Živkovićem. Režim se zasnivao na rigidnom i represivnom aparatu. Do krize je došlo nakon niza međunacionalnih sukoba, zbog tvrdog i konvencionalnog odnosa prema članicama Kraljevine SHS-a te brojnih gospodarskih afera u kojim su sudjelovale osobe iz javnoga i političkog života.

Kriza je kulminirala atentatom na petoricu hrvatskih zastupnika u beogradskoj Narodnoj skupštini. Ubijeni su Pavao Radić i Đuro Basariček, a Stjepan Radić, predsjednik Hrvatske seljačke stranke, Ivan Pernar i Ivan Granđa teško su ranjeni. Dana 8. kolovoza 1928. od zadobivenih je rana preminuo Stjepan Radić. Atentat i Radićeva smrt izazvali su bijes i ogorčenost $u$ hrvatskom narodu, koji je i sam bio izložen drastičnom progonu i uhićivanju svih režimu nepoćudnih osoba. Osim toga, kralj je donio Zakon o kraljevskoj vlasti i o vrhovnoj upravi (6. siječnja), Zakon o zaštiti javne bezbednosti i poretka u državi (6. siječnja), Zakon o državnom sudu za zaštitu države (8. siječnja) i Uredbe za izvršenje Zakona o Državnom sudu za zaštitu države (8. siječnja). ${ }^{1}$

Time je uveden žestoki centralizam i poduzete su represivne mjere prema svima koji su drugačije razmišljali ili djelovali. Zabranjena je također sloboda govora, uveden je verbalni delikt i cenzura, zabranjeno korištenje narodnog imena i dr. Cjelokupna moć režima bila je koncentrirana u kraljevim rukama. Na temelju Zakona o nazivu i podjeli Kraljevine na upravna područja (3. listopada) kralj Aleksandar je Kraljevinu SHS preimenovao u Kraljevinu Jugoslaviju i podijelio je na devet banovina (prostorno manja, deseta banovina, bila je Uprava grada Beograda), koje su svojim granicama negirale povijesne državnopravne entitete. Represija se protegnula na sve društvene slojeve pa su tisuće ljudi prošle kroz zatvore samo zbog vrijeđanja kralja, isticanja nacionalne zastave i sl. ${ }^{2}$

U Hrvatskoj je već 21. siječnja 1929. vodstvo Hrvatske pučke stranke primilo odluku ravnateljstva zagrebačke policije o raspuštanju stranke. ${ }^{3}$ Time je završio dugogodišnji rad "političke grane" Hrvatskoga katoličkog pokreta, iako su njegove ostale organizaci-

$1 \quad$ Hrvoje Matković, Povijest Jugoslavije, Naklada Pavičić. Zagreb, 1998., 163, Josip HORVAT, Politička povijest Hrvatske, II. dio, August Cesarec, Zagreb, 1990., 227.

2 H. Matković, n. dj., 164.

3 “Redarstveno raspuštanje HPS, HSS, HFSS, HSP”, Narodna politika, (1929.) 19, 1. 
je, predvođene Senioratom, nastavile i dalje djelovati. ${ }^{4}$ Diktatura kralja Aleksandra Karađorđevića bila je posve očekivano unitarna i jednostrana, rigidna i politički nepopustljiva prema političkim protivnicima. U Hrvatskoj je ukinuta banska čast, Sabor i hrvatsko državno pravo. Započelo je razdoblje sustavnog ekonomskog i gospodarskog izrabljivanja Hrvatske i Hrvata, napose nakon fizičke likvidacije hrvatskih zastupnika u Skupštini u Beogradu. ${ }^{5}$

U svome manifestu Karađorđević je sebe označio kao jedinog zakonodavca, koji cee ubuduće donositi zakone svojim ukazima, te zapovijeda i traži od svih da mu se pokoravaju. Njemu su podređeni svi žitelji države, a on nije odgovoran nikome. Srpski političari favorizirali su ideju nacionalnog jedinstva, a mislili su na stvaranje velike Srbije, eliminaciju katolicizma i islama te uvođenje pravoslavlja kao spasonosnog rješenja za sve narode na prostoru države. Katolička crkva bila je najveća prepreka takvu programu, te ju je trebalo ukloniti, najprije zbog njezine dosljednosti hrvatskoj tradiciji i kulturi.

U proklamaciji kralja Aleksandra I. Karađorđevića ističe se da je zadnji cilj njegova vladanja i najviši zakon zemlje narodno jedinstvo i državna cjelina. Pod narodnim jedinstvom podrazumijevalo se integralno jugoslavenstvo, kao najviši oblik nacionalne svijesti građana.

Središta kraljeve samovolje i favoriziranja ideje jugoslavenstva bile su kulturne i prosvjetne institucije, državni uredi te cjelokupan hrvatski prostor, koji je bio izložen ideji jugoslavenstva kao ideji nacionalnog jedinstva.

Među žrtvama Šestosiječanjske dikatature bio je i Hrvatski orlovski savez, kojemu je promptno izdano rješenje o zabrani rada i raspuštanju. Marica Stanković, svjedokinja svih događaja i njihova aktivna sudionica, u svojoj knjizi Mladost vedrine opisuje dramatične događaje koji su prethodili ukinuću i zabrani rada Hrvatskog orlovskog saveza: ${ }^{6}$ „Već u rujnu 1929. se moglo čuti da predsjednik

4 Opširnije o razvoju i djelovanju Katoličke akcije u Hrvatskoj nakon Ivana Merza, vidi: Zdravko Matić, Frano Stojić, Razvoj Katoličke akcije u Hrvatskoj nakon Ivana Merza, CUS, (2017.), 52, 219-248; Jure Krišto, Hrvatski katolički pokret 1903.1945., Glas Koncila - Hrvatski institut za povijest, Zagreb, 2004., 127.

5 H. Matković, n. dj., 167.

6 Marica Stanković, profesorica, kulturna i javna djelatnica (Zagreb, 31. prosinca 1900. - Zagreb, 8. listopada 1957.). Osnovnu, građansku i učiteljsku školu polazi kod Sestara milosrdnica u Zagrebu. U Zagrebu završava Višu pedagošku akademiju i kao nastavnica službuje u Podravskoj Slatini, Čakovcu, Kutini, Gračacu. Godine 1935. dobiva stalan posao u Zagrebu, u građanskoj školi. Bila je bliska suradnica dr. Ivana Merza. Nakon zabrane Orlovske organizacije sudjelovala je u osnivanju Križarske organizacije te je 1930. imenovana za predsjednicu Velikog križarskog sestrinstva. Zbog njezina javnog djelovanja komunističke su je vla- 
Vlade u Beogradu general Petar Živković namjerava likvidirati sva gimnastička društva u Jugoslaviji, da tako lakše provede jedinstvenu jugoslavensku organizaciju (...) Ipak se u studenom 1929. već znalo, da je Orlovstvu kraj, a u prosincu izašao je zakon o ukidanju gimnastičkih društava, pa i našega Orlovstva."7

Prije svoje likvidacije je preko glasila Za vjeru i dom svim svojim društvima poslala božićno pismo, u kojem se između redaka upozorava na bol zbog gubitka organizacije, ali i na utjehu koju donose božićne misli. ${ }^{8}$

\section{OSNIVANJE KRIŽARSKE ORGANIZACIJE}

Odmah nakon raspuštanja orlovstva, već u siječnju 1930., pripremao se osnutak nove organizacije, Križarske organizacije, koja će biti idejna baštinica orlovstva. ${ }^{9}$ Mali broj ljudi počeo se sastajati $\mathrm{u}$ odvjetničkoj kancelariji dr. Ivana Protulipca, ${ }^{10}$ na uglu Bakačeve ulice, ili u govornici isusovačkog samostana. ${ }^{11}$ Inicijativna skupina predvođena o. Josipom Vrbanekom, isusovcem, ${ }^{12}$ spremala se

sti osudile na pet godina zatvora. Slavica Tuškan: Ivan Merz, Marica Stanković $i$ zajednica Suradnica Krista Kralja, izlaganje na znanstvenom skupu, Obnovljeni život, 52 (1997.), 316.

7 Marica Stanković, Mladost vedrine, Zagreb, 1944., 55-56.

$8 \quad$ M. Stanković, n. dj., 56.

$9 \quad$ M. Stanković, n. dj., 61.

10 Ivan Protulipac, hrvatski pravnik i katolički djelatnik (Karlovac, 4. VII. 1899. Trst, 31. I. 1946.). Godine 1923. doktorirao je na Pravnom fakultetu u Zagrebu. Od 1923. do 1927. bio je odvjetnički pripravnik u Karlovcu, Bjelovaru i Zagrebu, a potom, do 1945., samostalni odvjetnik u Zagrebu. Bio je prvi predsjednik Hrvatskog orlovskog saveza u Zagrebu (1923. - 1929.) te Velikoga križarskoga bratstva (1931. - 1938.), u osnutku kojeg je sudjelovao. Godine 1936. bio je predsjednik Katoličke akcije za zagrebačku nadbiskupiju, a 1939. - 1941. sudjelovao je u radu Saveza hrvatskih junaka. Za Kraljevine Jugoslavije i Nezavisne Države Hrvatske više je puta bio zatvaran. U svibnju 1945. emigrirao je najprije u Austriju (Klagenfurt), a potom u Italiju (Rim, Trst). Ubijen je u siječnju 1946. po nalogu Udbe. Autor je knjige Hrvatsko orlovstvo (1926.)., Hrvatska enciklopedija, sv. 9, Leksikografski zavod Miroslav Krleža, Zagreb, 1999., 272.

11 Ivan Protulipac, Iz prvih dana Križarstva, Nedjelja (1936) 14-20, 26; M. Stanković, n. dj., 62, Božidar Nagy, Hrvatsko križarstvo, Križarska organizacija - Postulatura za beatifikaciju Ivana Merza, Zagreb, 1995., 92.

12 o. Josip Vrbanek, DI., suosnivač križarstva (Zorkovica, 4. X. 1882. - Sarajevo, 12. VI. 1945.). Gimnaziju i studij teologije završava u Zagrebu. Za biskupijskog svećenika zaređen je 1905. godine. U isusovački red stupa 1911. Novicijat je obavio u Zagrebu, a daljnje studije u Innsbrucku. Kad je beogradski režim dokinuo orlovstvo, zajedno s vodstvom dokinute organizacije osniva Križarstvo, koje njegovim zalaganjem postaje član Apostolata molitve; Božidar Nagy, Hrvatsko Križarstvo, Zagreb, 1995., 64-65. 
osnovati novu katoličku organizaciju u Hrvatskoj, prema uzoru na Hrvatski orlovski savez. Na prvim sastancima osim o. Josipa Vrbaneka bili su preč. g. dr. Milan Beluhan, ${ }^{13}$ Marica Stanković i dr. Avelin Ćepulić, ${ }^{14}$ koji su donijeli odluku o osnivanju nove organizacije, Križara. ${ }^{15} \mathrm{O}$ tome dr. Ivan Protulipac kaže: „Raspravljalo se kako da se u što zgodnijoj formi organizira i okupi rastepena hrvatska katolička mladež. Odlučeno je da se Episkopatu predloži osnivanje nove organizacije omladine pod imenom 'Križari' koja će biti u Apostolatu molitve, dok ne bude uređeno pitanje Katoličke Akcije."16 Napisana su i Pravila Križarske organizacije, koja su zapravo bila modifikacija Pravila Hrvatskog orlovskog saveza, prilagođena novom društvenom kontekstu. Nova organizacija postala je dijelom velike svjetske organizacije, Apostolata molitve, velikim zalaganjem isusovca o. Josipa Vrbaneka. ${ }^{17}$

Pravila, na kojima je osobno radio dr. Ivan Protulipac, predana su nadbiskupu Antunu Baueru, koji ih je temeljito proučio i odobrio 13. siječnja 1930. godine, pod brojem 258. ${ }^{18}$ Iste večeri je dr. Protulipac otputovao u Sarajevo nadbiskupu Ivanu Šariću, kojeg je zamolio da odobri Pravila, što je ovaj i učinio. Međutim, Pravila društva već je netko ranije dostavio predsjedniku Vlade i ministru unutarnjih poslova Peri Živkoviću, te je dr. Protulipcu prijetilo uhićenje. O tome sam Protulipac kaže: „Imao je u rukama pravila već 14. siječnja, na dan kada sam bio u Sarajevu. O tom, kako je on došao do pravila i prije nego što su bila po svim Ordinarijima odobrena i redovnim putem državne vlasti poslana na uvid, kolale su razne verzije, a među njima da ih je predala moja kancelarijska namještenica.

13 Mons. Milan Beluhan, generalni duhovnik Orlovske i Križarske organizacije (Pitomača, 21. V. 1877. - Zagreb, 21. I. 1953.). Rođen je u obitelji s dvanaestero djece. Gimnaziju je pohađao u Bjelovaru i Zagrebu, a teologiju je završio na Bogosloviji u Zagrebu. Od osnutka Orlovske organizacije bio je njezin generalni duhovnik, a od 1930. i duhovnik Križarske organizacije. Božidar Nagy, Hrvatsko križarstvo, Zagreb, 1995., 61.

14 M. Stanković, n. dj., 62, B. Nagy, n. dj., 90.

15 Ivo Protulipac, Uspomene iz nedavne prošlosti. Nedjelja, Zagreb, (1936.) 14, 20; B. Nagy, 95; Marica Stanković, Mladost vedrine, 62; Milan Beluhan, Povijest, ciljevi i metode rada Križarske organizacije, u: Vrhbosna 7-8, (1940.) 170, J. Krišto, Hrvatski katolički pokret 1903. - 1945., 192.

16 Ivo Protulipac, Uspomene iz nedavne prošlosti. Nedjelja, Zagreb, (1936.), 14, 20; B. Nagy, 93.

17 Crkvena organizacija Križari - Pravila; B. Nagy, Hrvatsko križarstvo, Zagreb, 1995., 90.

18 HR - Arhiv Hrvatske biskupske konferencije (dalje: HR - AHBK), Posebni fascikl “Križari” br. 36, Ivo Protulipac, Uspomene iz nedavne prošlosti. Nedjelja, Zagreb, (1936.) 14, 21. 
To je međutim isključeno, jer su ona umnažana sa svim oprezom. Činjenica jest da ih je g. Živković imao u rukama i da se silno ljutio, te je odredio da se mene u Sarajevu zatvori. Doznao sam kasnije da su me uistinu na stanici u Sarajevu čekali agenti, ali kako se mislilo da sam svećenik, nijesu me pronašli i ja sam otišao sutradan iz Sarajeva bez smetnje. Gospodin Živković se posebno ljutio, kako sam kasnije čuo od upućenih lica, na odredbu u pravilima o 'duhovnim vježbama' misleći da se radi o tjelovježbi!"19

Protulipac se vratio u Zagreb 16. siječnja, ali je već idući dan pošao u Beograd, pa zatim u Suboticu. Planirao je poći u Dalmaciju, da ponese Pravila i tamošnjim ordinarijima, uz zamolbu za njihovu potvrdu, no bio je spriječen pa su umjesto njega otputovali preč. dr. Beluhan i dr. Ćepulić. „Doznao sam kasnije, da su me i u Splitu i u Šibeniku čekali agenti, ali mene nije bilo!“20

Krčki biskup Josip Srebrnić odobrio je Pravila 18. siječnja 1930. godine. Problemi su se pojavili kada je policija presrela pismo dr. Protulipca upućeno splitskom župniku don Anti Braškiću, u kojemu mu piše: „Morate paziti da previše informacija ne dajete van, da gg seniori ne učine druk, kao što su u Zagrebu učinili. Organizacija će se dati provesti (...). Čim dobijete odobrena pravila od biskupa možete početi raditi u Splitu (...). Mi danas u Zagrebu počinjemo provoditi i već se društva u tom pogledu konstituiraju. Novi list 'Križ' izlazi tokom ovog tjedna. Još jedanput: pazite da stvar ne dobije nepoželjan publicitet, da ne bude nepotrebnih intervencija preko stvari(...).“21

Pismo je policija zaplijenila i proslijedila ga na znanje splitskom nadbiskupu dr. Bonefačiću osobno, koji je bio uznemiren, ali i vrlo oprezan. Dr. Protulipac je želio izbjeći utjecaj Seniorata, koji nije prestao „uhoditi“ i nametati se kao vrhovni starješina svim katoličkim organizacijama i nakon gašenja Orlovske organizacije. Upravo stoga dr. Protulipac je inzistirao na apolitičnosti organizacije i potpunom podvrgavanju Katoličkoj akciji, kako je osobno sve do svoje smrti radio i dr. Ivan Merz.

Zbog pisma koje je dr. Protulipac poslao don Anti Braškiću privedeni su na informativne razgovore biskup Bonefačić i biskup Akšamović, koji su upozoreni na posljedice ako se utvrdi da je nova Križarska organizacija istovjetna Hrvatskom orlovskom savezu.

19 Ivo Protulipac, Iz prvih dana Križarstva, Nedjelja, (1936.) 14, 7.

20 Ivo Protulipac, Iz prvih dana Križarstva, Nedjelja, (1936.) 14, 9.

21 Antun Pilepić, In aedificationem, Pismo svećenika braći svećenicima o problemima naše Katoličke Akcije, Split, 1938., 72. 
Nakon žestokih napada aktualne vlasti uslijedio je i napad tiska na Crkvu. Tako su se beogradske Novosti obrušile na Katoličku Crkvu i njezino vodstvo, s optužbom da se osniva "paravjerska“ organizacija koja više šteti nego koristi i koja je opasna za državu.

Policija je 27. siječnja 1930. obavila pretragu odvjetničkog ureda i stana dr. Ivana Protulipca te ga privremeno zatvorila. ${ }^{22}$ Uhićen je i priveden u policijsku postaju, gdje je cijeli dan trajala istraga. Zapisnik koji je na policiji sastavljen 27. siječnja 1930. govori o naravi i karakteru uhićenja dr. Protulipca. Posebna je pozornost bila posvećena listu Križ, koji je izišao početkom siječnja te se tražilo tko su članovi uredništva i konzorcija društva. ${ }^{23}$ Aktualnu vlast posebno je razljutio članak pod naslovom „U znaku križa“, koji je zapravo bio programatski članak dr. Protulipca, zbog čega je protiv njega pokrenut kazneni postupak. U istom članku sadržane su zapravo sve one ideje koje je dr. Protulipac propagirao tijekom dvadeset godina svojega javnog djelovanja. Upravo zbog tog članka dr. Protulipac je optužen prema Zakonu o zaštiti države; u predmetu pred Okružnim sudom u Zagrebu br. Kps 427/31 oslobođen je svake optužbe, jer Sud nije mogao pronaći ništa nezakonito. ${ }^{24}$

Zbog svih tih događaja zagrebački nadbiskup Antun Bauer boravio je u Beogradu od 29. do 31. siječnja 1930., gdje je snažno branio pozicije Križarske organizacije i Pravila za koja je tražio odobrenje.

Dana 5. veljače dr. Protulipac prebačen je u zatvor kod Sudbenog stola u ćeliju s političkim zatvorenicima, s potpunom izolacijom od vanjskog svijeta. Ministar Živković želio ga je upokoriti, kako bi odustao od ideje osnivanja Križarske organizacije. O tome dr. Protulipac kaže: „Za prvi čas bio sam smješten u ćeliji broj 19. s medicinarom Šabarićem, koji je bio pod optužbom zbog komunizma. Inače nije bio komunist, nego je samo zapao $u$ to. $U$ to vrijeme u zatvorima bilo je mnogo političkih ljudi među njima i dr. Budak, dr. Lebović itd. Međutim s njima nisam ostao dugo, samo jedan dan. Već sutradan pooštrene su mjere protiv mene; moj sudrug iz ćelije je maknut i ja sam ostao sam u ćeliji (...)“25

Zbog svega, nadbiskup Antun Bauer morao je ponovno putovati u Beograd, gdje je na njega izvršen snažan pritisak da obustavi rad

22 HR - HDA, fond SB DZ 24868/1931., Uprava policije u Zagrebu, Pov - Broj: 24.866-1931, KR. Banskoj upravi Savske Banovine, Odeljak državne zaštite, Izvadak iz političke evidencije, od 3. decembra 1931.

23 HR - DAZ, fond Kotarski sud, Kzp, 606-30, Sudska presuda; Ivo Protulipac, Iz prvih dana Križarstva, Nedjelja, br. 14. do 20, 1936.

24 HR - DAZ, fond Okružni sud, Kps 427/31, Sudska presuda.

25 Ivo Protulipac, Iz prvih dana Križarstva, Nedjelja, (1936.), 15, 17. 
križara. Na razgovoru u Ministarstvu pravde, 11. veljače 1930., od nadbiskupa Bauera zahtijevalo se da se „maknu“ sva sporna mjesta iz Pravila, tako da se vidi da se radi isključivo o vjerskoj organizaciji. Dva dana kasnije nadbiskupa Bauer dostavio je vlastima Pravila iz kojih su uklonjena sporna mjesta.

Ministarstvo pravde poslalo je 16. travnja 1930. dopis svim prvostupanjskim upravnim vlastima da ne ometaju osnivanje križarskih organizacija ako ostanu u strogo vjerskim okvirima. Unatoč svim pritiscima vlasti i policijskom praćenju križarskih društava koja su bila u osnivanju, održana je 6. travnja 1930. godine Osnivačka skupština Velikoga križarskog bratstva (VKB), glavnog vodstva Križarske organizacije. ${ }^{26}$

Dana 15. veljače pušten je iz zatvora dr. Ivo Protulipac, ali pravni postupak protiv njega nije bio obustavljen. Sudski postupak pokrenut protiv dr. Ivana Protulipca, dr. Avelina Čepulića i Gjure Jutriše zbog članka objavljenog u mjesečniku Križ nastavio se pred Kraljevskim kotarskim sudom I. u Zagrebu, pod predsjedanjem suca dr. Bastaića, 13. siječnja 1931., te su dr. Protulipac i drugovi proglašeni krivima.$^{27} \mathrm{Na}$ ponovljenom suđenju pred Kraljevskim sudbenim stolom u Zagrebu, koji se vodio pod predmetom broj: KPS 427/31 od 5. 5. 1932., dr. Protulipac i kolege oslobođeni su svake krivnje. ${ }^{28}$

\section{USTROJ KRIŽARSKE ORGANIZACIJE}

Križarska je organizacija bila vrlo dobro ustrojena. Već 1930. donesen je „Priručnik“ Križarske organizacije koji je sadržavao „Statut“, „Pravila“ i „Poslovnik križarske organizacije“. ${ }^{29}$ Prema Statutu „Križari“ su definirani kao rimokatoličko, crkveno i vjersko-prosvjetno udruženje. U 1. izdanju Statuta, odnosno Priručnika, iz 1930. g., piše da Križarska organizacija pripada Apostolatu molitve. Godine 1936. dolazi do promjene. Križarska organizacija napušta Apostolat molitve i ulazi u Katoličku akciju, prema želji nadbiskupa Alojzija Stepinca. ${ }^{30}$ Još za vrijeme studija u Parizu Ivan Merz upoznao se s francuskim Euharistijskim križarima, kod kojih mu se najviše svi-

26 Božo Goluža, Katolička crkva u Bosni i Hercegovini 1918.-1941., Mostar, 1995., 198.

27 HR - DAZ, fond Kr. kotarski sud, broj: Kps 3508-30, Sudska presuda.

28 HR - DAZ, fond Okružni sud, Kps 427/31 Sudska presuda od 5. 5. 1932.

29 HR - AIM, Priručnik Križarske organizacije, Zagreb, 1930.

30 HR - AIM, Priručnik Križarske organizacije, Zagreb, 1936., Već u 1. članku Pravilnika - Statuta stoji da su Križari rimokatoličko crkveno, vjersko-prosvjetno udruženje. Osnivaju se odobrenjem crkvene vlasti i spadaju u Katoličku akciju. 
đala njihova pobožnost prema Euharistiji. Od njih je uzeo lozinku „Žrtva - Euharistija - Apostolat“, koju je dao orlovstvu, a poslije ju je preuzelo i križarstvo. ${ }^{31}$

Svrha Križara bila je da okupe katoličku mladež za rad na vlastitom posvećenju i općoj vjerskoj i vjersko-prosvjetnoj obnovi po načelima Evanđelja. ${ }^{32}$ Križarstvo po svojoj definiciji obuhvaća čitavog čovjeka i usavršava ga u svjetlu Evanđelja, uputa Crkve i Svete Stolice. ${ }^{33}$

Prema Statutu, svrha Križara bila je da okupe katoličku mladež, odgoje ju, educiraju i pripreme za život i djelovanje u društvu. Da bi to ostvarili, nastojali su da članovi sudjeluju na crkvenim sastancima, mjesečno najmanje jednom, da žive po načelima katoličke vjere i svaki mjesec pristupaju svetoj pričesti. Svi članovi su trebali zajednički slaviti posebne križarske blagdane. Od članova se očekivalo da budu kršćanski obrazovani te društveno osjetljivi i spremni na zajedništvo. Upravo stoga su zamišljeni društveni sastanci (križarska sijela), poučna predavanja i tečajevi za proučavanje vjerskih, kulturnih, socijalnih i općenitih društvenih pitanja. Jedna od zadaća bila je urediti knjižnice, čitaonice, vježbati i održavati predstave, deklamacije itd. Tražilo se i njegovanje glazbe i pjevanja, posebno crkvene (liturgijske) glazbe, te poticanje i organiziranje zajedničkih izleta itd.

Jedna od važnih zadaća koja se tražila od članova Križara bila je širenje katoličke svijesti, održavanje poučnih vjerskih predavanja te širenje prosvjete među katoličkim pučanstvom, posebno borbom protiv psovke i kletve, radom za okupljanje širokih slojeva u vjerska društva, širenjem katoličkog tiska, organiziranjem različitih priredaba i predavanja, pomaganjem crkvenim vlastima u pastorizaciji, napose surađujući u katehetskom poučavanju vjernika te radom za misije $u$ vlastitim misijskim sekcijama. ${ }^{34}$

Krovna organizacija Križara bila je Veliko križarsko bratstvo (VKB), a središnjica ženskog dijela Križarske organizacije bila je Veliko križarsko sestrinstvo (VKS), sa sjedištem u Zagrebu. ${ }^{35}$ Ako je

31 Bila je to jedna od katoličkih organizacija za mlade u Francuskoj koja mu se najviše svidjela. Nastala je za vrijeme Prvoga svjetskog rata, kao dio Apostolata molitve, pod nazivom Croisade Eucharistique. Postoji i danas, pod nazivom Mouvement Eucharistique des Jeunes (Euharistijski pokret mladih) te okuplja oko 60.000 članova; B. Nagy, 116.

32 HR - AIM, Priručnik Križarske organizacije, Zagreb, 1930.

33 Joso Felicinović - Frane Grgić, NAŠ PUT - idejni i duhovni priručnik Križarske organizacije, Zagreb, 1936., 111.

34 HR - AIM, fond: Veliko križarsko bratstvo, Poslovnik Križarske organizacije, Zagreb, 1930.

35 HR - AIM, Zagreb, fond: Veliko križarsko bratstvo, Zapisnici sa sjednica od 1931. do 1945 . 
u pojedinim mjestima bilo više križarskih bratstava i sestrinstva, ona su se udruživala u mjesne križarske zajednice. Prema Poslovniku Križarske organizacije pokrajine su imale krajevna središta križarskih organizacija, a na razini biskupija postojala su križarska okružja.

Mjesnu križarsku zajednicu činio je skup svih križarskih društava u jednome mjestu, bez obzira na stalešku pripadnost članova, a krajevnu križarsku organizaciju činile su sve križarske organizacije pojedinih mjesta koje su bile formalno pod krajevnoj nadležnosti.

Križarsko okružje prema Poslovniku činila su križarska bratstva s područja jedne biskupije. Sva su društva i okružja bila u Velikom križarskom bratstvu, koje je bilo njihova središnjica. ${ }^{36}$

Staleške zajednice Križarske organizacije činile su Seljačka, Radnička i Gradska križarska mladež, Mahnićeva đačka križarska mladež te Zajednica križarskih starješina. ${ }^{37}$

Unutarnju upravu križarskih društava činili su odbor, preglednički odbor, društvena glavna skupština, društveni sud i časni sud. Na čelu odbora bio je duhovnik društva (svećenik), zatim predsjednik, potpredsjednik, tajnik, blagajnik, vođa malih križara, vođa naučnika i knjižničar. ${ }^{38}$

Priručnikom je bilo propisan točan postupak osnivanja križarskog društva, koje sve formalne uvjete treba ispuniti prilikom osnivanja: kako započeti djelatnost, što treba raditi predsjednik, tajnik, blagajnik, kako urediti knjižnicu itd.

Križarska organizacija bila je podijeljena na muški i ženski dio, u okviru kojih su postojala pojedina društva, bratstva ili sestrinstva. Rad se odvijao prema tada prihvaćenom i prakticiranom načelu o odijeljenosti odgoja muške i ženske mladeži. ${ }^{39}$ Priručnikom je propisano i osnivanje, funkcioniranje i djelovanje glazbenih društava. Navedene su precizno sve formalnosti koje treba ispuniti prilikom osnivanja, kako započeti djelatnost, koja je pravna uloga predsjednika, tajnika i blagajnika te kako organizirati križarske priredbe, javne manifestacije, povorke i druge aktivnosti. ${ }^{40}$

36 HR - AIM, fond: Veliko križarsko bratstvo, Poslovnik Križarske organizacije, Zagreb, 1930., 8.

37 HR - AIM, fond: Veliko križarsko bratstvo, Poslovnik Križarske organizacije, Zagreb, 1930., 10-13.

38 Isto, 12.

39 HR - AIM, fond: Veliko križarsko bratstvo, Poslovnik Križarske organizacije, Zagreb, 1930., 59.

40 HR - AIM, fond: Veliko križarsko bratstvo, Poslovnik Križarske organizacije, Zagreb, 1930., 77. 
Križari su imali i svoj tisak. Tako je uz tjednik Nedjelja, koji je nastavio izlaziti i nakon zabrane orlovstva 1929., u siječnju 1930. počeo izlaziti Križ, službeno glasilo Križarske organizacije, koje je od 1934. promijenilo ime u Križarska straža. Postojao je i mjesečnik Socijalni rad (1937./1939.), list za najmlađe Vrtić (1931.), a mnoga mjesna križarska društva imala su svoje lokalne listove. ${ }^{41}$

\section{DJELOVANJE KRIŽARSKE ORGANIZACIJE OD 1931. DO 1941. GODINE}

Novoutemeljena Križarska organizacija bila je izložena progonima od strane beogradskog režima već od samoga početka, kako zbog samog poslanja Križarske organizacije, tako i zbog njezina oportunog djelovanja prema organizaciji Jugoslavenskog sokola, koji je bio nametan katoličkoj mladeži. Upravo je stoga Biskupska konferencija Jugoslavije 17. studenoga 1931. donijela Poslanicu u kojoj je pozvala roditelje katoličke mladeži da ne učlanjuju svoju djecu u Jugoslavenski sokol. ${ }^{42}$

Bila je uobičajena praksa da članovi VKB-a posjećuju društva u pokrajini, održavaju predavanja i tečajeve te tako održavaju usku povezanost sa središnjicom. Teme o kojima se raspravljalo na sastancima VKB-a, bile su organiziranje i održavanje duhovnih vježbi, tečajeva i ljetnih praznika, proslave križarskih blagdana, napose Papina dana i obljetnice smrti dr. Ivana Merza, organiziranje hodočašća i izleta, sudjelovanje križara na crkvenim proslavama, pisanje i izdavanje križarskih okružnica, knjiga, glasila i drugog materijala, rješavanje raznih financijskih, disciplinskih i drugih aktualnih pitanja koja se tiču organizacije u širem smislu.

Godina 1933. bila je po mnogočemu posebna. U Njemačkoj su došli na vlast nacionalsocijalisti, pa se povećao sukob između Crkve i državnih vlasti. Na prostoru Kraljevine Jugoslavije nisu popuštale tenzije u odnosu prema Katoličkoj Crkvi i katoličkim organizacijama. Papa Pio XI. skrenuo je pozornost beogradskim vlastima preko Nikole Moscatellija kako se od njih očekuje da poštuju ljudska prava i slobodu ispovijedanja vjere. Jer, kako je Sveta Stolica primijetila, položaj katolika u državi vrlo je nepovoljan. ${ }^{43}$ Naravno, Vlada u Beogradu

41 V. Kunić, Križarski društveni listovi, u Križ, (1931.) 2., 18-19.

42 HR - AHBK, Zapisnik konferencija jugoslavenskog katoličkog episkopata 1931., I. Ćubelić, Biskupske konferencije Jugoslavije, 532.

43 Tomislav Jonjić, Hrvatska vanjska politika 1903.-1945., Zagreb, 2000., 219. 
svalila je krivnju na katoličke biskupe te njihovu tzv. „samovolju“ i odbijanje suradnje s vlastima. Situacija se dodatno zakomplicirala kad je predsjednik Jugoslavenskog sokola iz Zagreba Oton Gavrančić, s još 61 poslanikom, podnio u Narodnoj skupštini u Beogradu prijedlog da se zabrani rad Družbe Isusove, što je izazvalo snažne reakcije među katolicima i biskupima u Kraljevini Jugoslaviji. ${ }^{44}$ Zbog takvog ponašanja beogradskih vlasti papa Pio XI. odbio je 20. travnja 1933. primiti parlamentarnu delegaciju Kraljevine Jugoslavije. ${ }^{45}$

Godine 1934. Alojzije Stepinac izabran je za nadbiskupa koadjutora s pravom nasljedstva u zagrebačkoj nadbiskupiji. Mnogi su Stepinčev dolazak ocijenili pozitivnim, a njega su ocijenili kao čovjeka velikih, ali odmjerenih koraka. Prvi potez koji je napravio nadbiskup koadjutor Stepinac, bila je anketa koja je provedena među katoličkim intelektualcima i promicateljima kršćanskih vrijednosti. Cilj ankete bio je utvrditi kakvo je raspoloženje i stanje unutar katoličkih organizacija. Za anketu su bili zamoljeni i hvarski biskup Miho Pušić te Petar Grgec, vlč. Dragutin Kniewald, vlč. dr. Pavao Lončar i vlč. Augustin Wolf. Prema riječima Petra Grgeca, uglednog katoličkog intelektualca i seniora, za neuspjeh i konfuzno stanje unutar katoličkih organizacija najviše je bio odgovoran Episkopat, koji zapravo nikada nije preuzeo potpun nadzor nad Katoličkom akcijom. To je samo dijelom točno, jer treba uzeti u obzir činjenicu kako je upravo Hrvatski katolički seniorat dugi niz godina, zapravo od osnutka Hrvatskog orlovskog saveza 1923., sustavno provodio nadzor nad svim katoličkim organizacijama i nametao se kao ekskluzivna organizacija, koja treba imati uvid u aktivnosti svih organizacija, a da pritom nikome ne odgovara. ${ }^{46}$

Ni godina koja je uslijedila nije donijela ništa novo u području rada katoličkih organizacija. Križarska je organizacije nailazila na niz poteškoća zbog aktualne vlasti. S druge strane, revni je Seniorat, iako je odustao od reanimiranja političke stranke, pozorno pratio aktualne događaje i rad Križarske organizacije, koju je diskretno nadzirao i savjetovao u radu. Unatoč diskretnosti Seniorata Odsjek za državnu zaštitu Kraljevske banske uprave Savske banovine poslao je 22. veljače 1935. dopis Upravi policije u Zagrebu, svim kotarskim načelnicima i svim predstojnicima gradskih policija da je izvijeste o broju i aktivnostima križara, napose nakon objavljivanja okružnice nadbiskupa dr. Antuna Bauera o Katoličkoj akciji. Sukladno

44 Stjepan Bakšić, Zašto Isusovce tjeraju u progonstvo, Katolički list, (1933.) 8,72-79.

45 Tomislav Jonjić, Hrvatska vanjska politika 1903.-1945., Zagreb, 2000., 220-223.

46 HR - AHBK, Posebni fascikl „Uređenje Katoličke Akcije“, br. 34, cit. u: Ivan Ćubelić; Biskupske konferencije Jugoslavije, 534. 
naputku policija je povećala nadzor nad svim križarskim okružjima. ${ }^{47}$ Započela su i privođenja, provođene su pretrage službenih prostorija križarskih organizacija, te su kažnjavane zbog posjedovanja službenih materijala, plakata, znački ili zastava VKB-a. ${ }^{48}$ Unatoč pritiscima vlasti križarske organizacije pronašle su put za svoje djelovanje.

Kako su izgledale sjednice Velikog križarskog bratstva doznajemo iz zapisnika koji su se sačuvali. Donosimo ovdje kao uzorak i za ilustraciju zapisnik 23. sjednice VKB-a od 13. veljače 1935.

Sjednici su nazočili dr. Ivan Protulipac, dr. Avelin Ćepulić, S. Šarić, S. Ramljak, Stiperski, Malinar, I. Tubaković i Frane Grgić kao izvjestitelj. Spominje se da su Križarske organizacije bile prisutne u Novskoj, Novoj Gradiški, Lipovljanima, Vrbju, Novoj Gradiški, Davoru, Orubici - Staro Petrovo Selo. Prema izvješću dr. Ćepulić je bio u Koprivnici i održao sastanak s malim križarima. Radi se na omasovljenju zajednice i rješavanju aktualnih problema. Dr. Protulipac je bio u Petrinji te je zadovoljan onim što je vidio. Organizacija Papinske priredbe bila je na zavidnoj razini. Cijelo mjesto je uspješno. ${ }^{49}$ Osnovano je Križarsko bratstvo u Sladojevcima i Križarsko bratstvo starješina u Baškoj na Krku. U osnivanju je bilo Križarsko bratstvo u Aleksandrovu (Punat) na Krku. U Sv. Mariji pod Okićem bilo je obustavljeno djelovanje, no mjesni je župnik odlučio ponovno pokrenuti rad Organizacije. U Zagrebu su započele duhovne vježbe, kojima je nazočilo 15 sudionika. Dr. Protulipac je čestitao 80. rođendan nadbiskupu Antunu Baueru, te je tom prilikom nadbiskup obećao da će i nadalje podupirati rad Križarske organizacije. Dogovorene su nove aktivnosti i djelovanje Križarske organizacije. ${ }^{50}$

Križarska društva postojala su u svim hrvatskim biskupijama. Najbrojnija su u biskupijama zagrebačkoj, đakovačkoj, vrhbosanskoj, šibensko-zadarskoj i subotičkoj. Ali i u ostalim biskupijama nisu zaostajala: splitskoj, dubrovačkoj, hvarskoj, kotorskoj, banjolučkoj i mostarskoj. ${ }^{51}$ Iako je glavni arhiv Križarske organizacije zaplijenila OZNA, na temelju Križarskog kalendara za 1937. godinu poznato je da je ukupno bilo 430 križarskih bratstava i 206 zborova malih križara. Ukupan broj križara bio je 22.800. Budući da su kri-

47 HR - HDA, Fond: Kraljevska banska uprava Savske banovine, Otsek za državnu zaštitu, Pov. II. D. Z. broj 8509-1935, Zagreb, 22. Februara 1935.

48 HR - AHBK, Posebni fascikl, „Katolička Akcija - Orlovi - Križari“, 36, Žalba Ministarstvu unutarnjih poslova u Beogradu zbog progona Križara.

49 HR - Arhiv dr. Lava Znidarčića, (dalje: ALZ) Fond: Križarstvo, Zapisnici Velikog Križarskog Bratstva 1930-1945.

50 HR - ALZ, Fond: Križarstvo, Zapisnici Velikog Križarskog Bratstva 1930-1945.

$51 \quad$ B. Nagy, n. dj., 158. 
žarska bratstva bila podijeljena po staležima, bilo je oko 1000 đaka srednjoškolaca, 4610 radnika, 8700 seljaka i 8490 malih križara (dječaka do 15 godina). Godinu dana poslije, 1938., bila su 783 križarska bratstva, sa 26.689 križara, što je bio vrhunac koji je postigla muška grana Križarske organizacije.

Što se tiče ženske grane križarstva, ona je brojčano bila manja od muške. Prema Križarskom kalendaru za 1937. djevojaka križarica bilo je 12.200; godinu dana poslije, 1938., bila su 123 društva seoskih djevojaka; 74 društva djevojaka radnica; 25 društava djevojaka učenica srednjih škola; 185 društava malih križarica i 7 društava križarskih starješica. Ukupno je 1938. godine bilo 414 društava (sestrinstva), koja su obuhvaćala 15.000 djevojaka križarica. Križarska organizacija doživjela je svoj najveći uspon 1938. godine, kada je brojila oko 40.000 križara i križarica. ${ }^{52}$

Na sjednici VKB-a održanoj 6. listopada 1937. njezin predsjednik dr. Ivan Protulipac predložio je nova tijela u strukturi unutarnjeg poslovanjaVKB-a.Takosuustrojeneslužbereferentazatisakizapropagandu. ${ }^{53}$

Međutim, nisu svi biskupi bili zadovoljni stanjem u Križarskoj organizaciji, napose Srebrnić, Pušić i Akšamović, koji su kritički gledali na rad dr. Protulipca te su zatražili da podnese ostavku na mjesto predsjednika Velikoga križarskog bratstva. Kad je nadbiskup Stepinac imenovao Protulipca za predsjednikom Katoličke akcije, on više nije mogao biti i predsjednik Križarske organizacije. Na novoj dužnosti Protulipac je ostao šest mjeseci, a onda je podnio ostavku. Odmah se dao na osnivanje dvaju katoličkih društava: Mladost i Hrvatskijunak. U te organizacije ulazili su djelomično i križari. Nadbiskup Stepinac je 22. veljače 1939. izdao okružnicu o tome da se oni koji žele sudjelovati u Katoličkoj akciji, koja je bila glavna točka njegove reforme katoličkih organizacija, ne bi se trebali uključivati u nove organizacije.

Naime, reforma na kojoj je novi zagrebački nadbiskup inzistirao, odnosila se na sve đačke i studentske katoličke organizacije, koje bi sukladno naputku Svete Stolice trebale biti pod krovnom organizacijom, Katoličkom akcijom. Time bi se otklonila opasnost od raznih zlouporaba i „liderstva“ kao i favoriziranja pojedenih grupacija unutar katoličkih intelektualaca koji su i tada sebe stavljali u prvi plan, kao što je bio Seniorat, koji je od svojega osnutka 1912. godine i nakon gotovo tri desetljeća svojega djelovanja sebe smatrao vrhovnim forumom unutar Hrvatskoga katoličkog pokreta. Upravo

52 Križarski kalendar za 1937. i 1938. godinu.

53 HR - ALZ, fond: Križarstvo, kut. 3., Zapisnik sjednice Velikog križarskog bratstva od 6. listopada 1937. godine. 
zbog bojazni od moguće politizacije s bilo koje strane, Stepinac je želio da to pitanje riješi na način da sve organizacije budu pod okriljem Katoličke akcije, upravo onako kako je papa Pio XI. u svojoj enciklici Ubi arcano Dei, naznačio, a dr. Ivan Merz poslije u Hrvatskoj od 1923. pa sve do svoje smrti i provodio. ${ }^{54}$

Na proljetnom zasjedanju Biskupske konferencije održanom u ožujku 1939. godine osim biskupa Kraljevine Jugoslavije sudjelovao je i apostolski nuncij Etore Felici, ${ }^{55}$ koji je u svome izlaganju rekao da je neutemeljeno govoriti o raznim „tipovima Katoličke akcije“ te favorizirati na bilo koji način rješavanje statusa katoličkih organizacija putem tog modela. Nuncij je mišljenja da treba sve katoličke organizacije nivelirati i dovesti pod jedinstvenu krovnu organizaciju, koja se zove Katolička akcija i koja će biti pod vodstvom i nadzorom Episkopata. Bio je to dosta oštar govor, kojim je nuncij želio poručiti Episkopatu da i sam treba tražiti upravo takvo rješenje za nastale probleme. ${ }^{56}$

Dio biskupa ostao je dosljedan Križarima, poput nadbiskupa Šarića, koji je inače branio Križarsku organizaciju. Nadbiskup Stepinac se složio s nuncijem i podupro njegovo stajalište da sve organizacije koje djeluju jesu zapravo „tipovi“ organizacija. ${ }^{57}$

Na jesenskom zasjedanju Biskupske konferencije Kraljevine Jugoslavije 1939. između ostalog se raspravljalo o ustanovljenju Kršćanskih mladih radnika i radnica, s čime se nije složio nadbiskup Šarić, jer je u tome vidio opasnost od eliminacije Križara. Osim toga, smatrao je da se „pretjeruje“ s eksperimentiranjem oko Katoličke akcije. ${ }^{58}$ Replicirao mu je krčki biskup Srebrnić, koji je istaknuo da se Križarsko radništvo gotovo potpuno raspalo i da de facto križarska društva masovno prelaze u Mladost i Hrvatskijunak, društva koja je osnovao dr. Ivan Protulipac. ${ }^{59}$

54 I. Ćubelić, Biskupske konferencije Jugoslavije, 539.

55 Ettore Felici (1881. - 1951.) imenovan 20. travnja 1938. apostolskim nuncijem u Kraljevini Jugoslaviji. Otišao je iz Beograda 29. svibnja 1941., boravio u Zavodu sv. Jeronima od 2. lipnja 1941. do kraja 1942. Vodi se kao nuncij u Jugoslaviji do 15. siječnja 1946., kad je imenovan mons. Patrick Hurley Reggente della Nunziatura. Vidi "Papino priznanje svjetovnih država", u: Vatikan i Dubrovnik (ur. Ž. Puljić), Dubrovnik, 1994., 78.

56 I. Ćubelić, Biskupske konferencije Jugoslavije, 539.

57 HR - AHBK, Zapisnik sjednice Katoličkog episkopata Kraljevine Jugoslavije, nav. prema I. ĆUBELIĆ, Biskupske konferencije Jugoslavije, 540.

58 HR - AHBK, Posebni fascikl br. 14., "Katolička Akcija 1939.-1945., Dr. Ivan Šarić, nadbiskup vrhbosanski, Pismo Predsjedništvu BK u vezi odluke o KA sa zasjedanja 1939., I. Ćubelić, Biskupske konferencije Jugoslavije, 540-541.

59 HR - AHBK, Posebni fascikl br. 14, "Katolička Akcija 1939.-1945.“, I. Ćubelić, Biskupske konferencije Jugoslavije, 541. 
5. DJelovanje KriŽarske organizaciJe u VRIJEME NeZavisne DRŽAVE HRVATSKE (1941. - 1945.)

Hrvati su s velikim oduševljenjem prihvatili uspostavu Nezavisne Države Hrvatske 10. travnja 1941. Zagrebački nadbiskup Alojzije Stepinac izdao je 28. travnja 1941. okružnicu kojom je izrazio dobrodošlicu i radost zbog uspostave hrvatske države. ${ }^{60}$ Prvi broj Nedjelje, od 27. travnja 1941., donosi na naslovnoj stranici sliku poglavnika dr. Ante Pavelićeva i uvodnik pod naslovom: „Obnovljena je Nezavisna Država Hrvatska“. U tom članku slavi se osnivanje NDH, poglavnik Ante Pavelić i prva izabrana vlada. U naslovniku se navodi da su Pavelić i Stepinac uspostavili najsrdačnije odnose između Katoličke Crkve i „Države Hrvatske“. 61

Drugi broj Nedjelje, od 4. svibnja 1941., donosi poziv Predsjedništva Velikoga križarskog bratstva svim podružnicama u provinciji, u kojem se među ostalim kaže: „Naši su članovi od početka organizacijskog djelovanja bili uvijek u prvim redovima narodne borbe. Stoga nije ni čudo ako bi u ovim teškim danima koje smo do nedavna proživljavali bilo Križara koji su i živote položili na oltar domovine. Da bi dostojno počastili uspomenu naših prvo boraca i mučenika potrebno je da bratstva odmah pošalju Velikom Križarskom Bratstvu opis svih onih članova koji su u borbama ili na bilo koji način poginuli (...)."62

Osim poslanice nadbiskupa Stepinca od 28. travnja 1941. taj broj donosi i članak o. J. Jadrovskog, u kojemu se među ostalim kaže: „A koja je uloga Križara u novoj Hrvatskoj? U prvom su dijelu narodne borbe Križari osvojili mnogo radnika i boraca koji su svojim radom, žrtvama pa i svojim životima posvjedočili svoju ljubav prema Hrvatskoj. Križarstvo je u deset godina svoga rada dalo Hrvatskoj pokoljenje svjesnih hrvatskih narodnih sinova. U drugom dijelu narodne borbe imaju Križari vrlo važnu i veliku zadaću ispuniti."63

O tome kako su Križari djelovali za vrijeme Drugoga svjetskog rata u Nezavisnoj Državi Hrvatskoj, najbolje svjedoči njezin dugogodišnji predsjednik dr. Lav Znidarčić.

„Kratki 'travanjski rat', propast Jugoslavije i stvaranje NDH-a doveli su i Križarsku organizaciju pred nove probleme. Križari su, kao i čitav hrvatski narod, dočekali propast Jugoslavije s veseljem

60 J. Krišto, Sukob simbola. Vjera, politika i ideologija u NDH, Zagreb, 2001., 127.

61 Obnovljena je Nezavisna Država Hrvatske, Nedjelja, (1941), 15, 3.

62 Nedjelja, (1941.), 16, 5.

63 Nedjelja, (1941.), 16, 7. 
i nadom. Prva razočarenja i štete nastali su prilikom određivanja nepravednih i nepovoljnih državnih granica. Pod tuđom su državnom upravom ostala brojna Križarska bratstva i čak čitava Križarska okružja (Bačka, Kotor, Krk, Međimurje, dio Senja, Šibenika, Splita i Dubrovnika). Organizacija se našla u vrlo teškoj situaciji.

Nova vlast u NDH nije bila neprijateljski raspoložena prema Križarskoj organizaciji, ali kako se radilo o totalitarnom režimu, ustaški je pokret formirao svoju posebnu omladinsku organizaciju nazvanom 'Ustaška mladež', koja je težila sveobuhvatnosti i koja nije dobro gledala one, koji se nisu učlanili u njezine redove. Takvi su najprije, i u pravilu bili križari. To je na terenu stvaralo nemale probleme, a bilo je i neugodnosti za križare. Poseban su problem bila križarska glasila, osobito 'Nedjelja' koju je 'preventivna' cenzura često dovodila u nezgodan položaj. Kasnije je bilo i otvorenih napadaja.

Na primanju kod Poglavnika dne 19. lipnja 1941. Pavelić je pozvao predstavnike katoličkih organizacija na sastanak i razgovora s njime. Taj je sastanak održan 16. srpnja 1941. god. u Banskim dvorima. Križarsku su organizaciju predstavljali: generalni duhovnik Msgr. Dr. Milan Beluhan, Stjepan Ramljak, potpredsjednik VKB, prof. Marica Stanković, predsjednica VKS i Lav Znidarčić kao tajnik VKB-a. ${ }^{64}$ Sastanak je održan kasno poslije podne i trajao je oko jedan sat. Osim Poglavnika 's druge strane' nije nitko prisustvovao. Govorilo se o svim pitanjima odgoja mladeži, a u toku razgovora Poglavnik je izjavio da će biti prisiljen raspustiti sve katoličke organizacije u NDH, jer da Vatikan odbija priznati NDH. Sastanak je završio s nikakvim konkretnim rezultatom. O onome što smo čuli od Poglavnika odmah je bio obaviješten Nadbiskup Stepinac, a vodstvo organizacije održalo je nakon nekoliko dana posebnu „tajnu“ sjednicu. Do zabrane Križarskih i ostalih postojećih katoličkih organizacija stvarno nije došlo. Pavelića su sigurno upozorili, da je to i pravno nemoguće, jer se radi o Katoličkoj Akciji, koja je pod neposrednom upravom hijerarhije i takva bi 'odluka' značila otvoreni sukob s Crkvom. Križari su za vrijeme rata, slijedeći sudbinu svoga

64 Osim njih u delegaciji su bili: vlč. Ilinko Weber iz Senja, vlč Ivan Mihalić iz Gospića, prof. Mirko Cerovac, prof. Vjenceslav Pech, ing. Slavko Brođanac, ing. Nikola Kirigin, Ivica Glovacki, Ljeposav Perinić, Ivica Krilić, Ante Lenić, Anto šikić, Ivica Cerovac, Ivan Marović I Krešo Mutabdžija. U ime Velikog križarskog sestrinstva osim prof. Marice Stanković bile su: Vlasta Arnold, prof. Đurđica Vitković, Mira Preisler, Ivanka Dokopil, Mira Dugački, Jelka Maretić, Anica Bođakoš, Jurka Huljev, Mara Čović, Darinka Dugački, Ivka Špes i Marija Belković; Posjet Poglavniku - Vodstvo Velikog Križarskog Bratstva i Sestrinstva posjetilo je Suverena Nezavisne Države Hrvatske, Poglavnika dr. Antu Pavelića; Nedjelja (1941.) 25, od 29. 3. 
naroda, ginuli na svim bojištima, na jednoj i na drugoj strani, redovito mobilizirani od konkretne vlasti, na području gdje su živjeli."65 Jedan dio vodećih osoba križarstva priključio se ustaškom režimu, između ostalih: Ivan Oršanić, Felix Niedzielski, Dušan Žanko, Ivan Cerovac i drugi. Dio istaknutih članova Seniorata pronašao je posao u državnoj službi NDH: Ljubomir Maraković, Petar Grgec, J. Penić, Janko Šimrak, Ante Živković, a jedan dio članova bili su u oporbi režimu: Gortan, Sironić, Ujević, Deželić. ${ }^{66}$

Koncem 1940. za novoga (trećeg po redu) predsjednika Velikoga križarskog bratstva izabran je dr. Felix Niedzielski (1912. - 1947.), podrijetlom Poljak, koji je poput Ivana Merza prihvatio Hrvatsku kao svoju domovinu. Bio je pravnik po struci, a u rad Križarske organizacije uključio se 1933. godine. Bio je revan član Križarske organizacije, a kada je postao predsjednik VKB-a, bio je „mladi gorljivi vjernik, katolik cijelim svojim bićem, odan proučavanju i promicanju kršćanskog poimanja o društvu, čovjek kojemu je molitva bila svakodnevno disanje duše i koji ne bi mogao živjeti bez euharistije“ ${ }^{67}$

Predsjedništvo Velikoga križarskog bratstva u Zagrebu izdalo je početkom svibnja 1941. proglas u kojemu su pozvali svoje članove da još predanije $u$ hrvatskoj državi rade na ostvarenju križarskih ideala i stvaranju pravednoga društva koje će se temeljiti na kršćanskim vrijednostima. 68

Na kraju kalendarske godine, 8. prosinca 1941., Križari su na službenom primanju kod predstavnika Svete Stolice u Zagrebu mons. Ramira Marconea, još jednom istaknuli svoju predanost apostolatu, euharistiji i žrtvi te odanost Svetoj Stolici. ${ }^{69}$ Budući da je dr. Felix Niedzielski bio imenovan od civilnih vlasti na dužnost podžupana u Velikoj župi Usora i Soli u Tuzli, nadbiskup Stepinac ga je zamolio da podnese ostavku kao predsjednik Križarske organizacije, što je on i učinio. ${ }^{70}$

U ožujku 1942. za novog predsjednika VKB-a izabran je dotadašnji tajnik dr. Lav Znidarčić, koji je tijekom cijeloga rata bio „politički apstinent“, kako su ga u svojim izvješćima opisali suradnici

65 HR - ALZ, fond: Križarstvo, kut. 3, rukopis, Posjet Poglavniku - Vodstvo Velikog Križarskog Bratstva i Sestrinstva posjetilo je Suverena Nezavisne Države Hrvatske, Poglavnika dr. Antu Pavelića, Nedjelja (1941.) 25, 3.

66 HR - HDA, fond: MUP-a RH-a, 001.4, br. 2, kut. 9,2; J. Krišto, n. dj., 235.

67 Živko Kustić, Četrdeset peta obljetnica strijeljanja dr. Feliksa Niedzielskoga, u: Glas Koncila, (1992.), 8, 13.

68 Katolički Tjednik, (1941.) 21, 3.

69 Katolički Tjednik, (1942.) 4, 5.

70 Katolički Tjednik, (1942.) 20, 4, Pismo ostavke. 
Udbe. ${ }^{71}$ To mu je vjerojatno spasilo život, ali kao pravnik i predsjednik VKB-a u svojim je javnim nastupima naglašavao da „križarstvo nije i ne može biti politički angažirano“.

Tijekom 1942. godine rat je tinjao na području cijele Hrvatske i Bosne i Hercegovine. Episkopatu je bilo više nego jasno da vladajući režim NDH odlazi u jednu drugu, „bezizlaznu“ situaciju, iz koje više nema povratka. Iste godine razvijaju se nova bojišta i bojišnice diljem Bosne i Hercegovine. Josip Broz Tito je sa svojim partizanima zauzeo zapadnu Bosnu oko Bihaća. Većina članova križarskih okružja mobilizirana je ili su se priključili partizanskom pokretu. Vodstvo Križara na čelu s tadašnjim predsjednikom dr. Lavom Znidarčićem zabranilo je svojim članovima bilo kakav javni nastup te ih pozvalo da još snažnije prionu molitvama. ${ }^{72}$

I tijekom 1943. križarska društva nastavila su sa svojim radom. Sukladno Poslovniku, unatoč ratnim prilikama, održavale su se duhovne vježbe, organizirali seminari, predavanja i druge aktivnosti. Brojni tekstovi u sarajevskom Katoličkom tjedniku ublažili su svoju retoriku, napose o „rasnim pitanjima“, te su upozoravali na opasnost ekstremizma, s bilo koje strane dolazio. Vodstvo VKB-a je u tjedniku Nedjelja istaknulo da se križarstvo ne smije smatrati "podmlatkom bilo koje političke stranke“, ${ }^{73}$ budući da je jedan dio križara pristao uz ustašku ideologiju. Takvu opasnost vrlo je rano prepoznao predsjednik Organizacije dr. Lav Znidarčić, koji je u svim svojim javnim nastupima naglašavao važnost političke „apstinencije“ za članove Križarske organizacije. Štoviše, dr. Znidarčić je isticao duhovnu dimenziju djelovanja svih katoličkih organizacija, koje moraju biti čuvari duhovnog integriteta cijele Katoličke Crkve. ${ }^{74}$ Kao dugogodišnjem članu najprije Orlovske, a zatim Križarske organizacije bile su mu dobro poznate ideje Katoličke akcije, za koje se zalagao Ivan Merz, koji je i uveo Katoličku akciju u Crkvu u Hrvata. Jedna od glavnih ideja Katoličke akcije bila je upravo izvanpolitičnost katoličkih organizacija i njihova podređenost Episkopatu.

Dr. Lav Znidarčić je 1943. ponovno izabran za predsjednika VKB-a. Novi članovi Predsjedništva bili su: F. Niedzielski, prvi potpredsjednik, Mirko Cerovac, drugi potpredsjednik, Ljeposav Perinić, tajnik, Bartol Blašković, blagajnik, don Jozo Felicinović i Nikola Machulka, prosvjetni izvjestitelji, Petar Šimunić, predsjednik Đačke zajednice, Frane Lukić, predsjednik Seljačke zajednice, Rudo Škor-

71 HR - HDA, Fond: RSUP SRH, 001.4, br. 1, kut. 9, Katoličke organizacije

72 U dubinu, Katolički tjednik, (1942.) 43, 1.

73 Katolički tjednik, (1943.) 38, 4.

74 Je li Križarstvo suvremeno?, Katolički tjednik, (1943.) 38, 4. 
lić, predsjednik Radničke zajednice, Zvonko Sabljak, savezni vođa Malih križara, Ante Jerkov, izvjestitelj za tisak, te preč. Ante Krešo Zorić, član Velikoga križarskog bratstva.

Prigodom proslave 20. godišnjice orlovstva, koje je osnovano 16. prosinca 1923., u prosincu 1943. godine, i križarstva, koje predstavlja idejni kontinuitet djelovanja orlovstva, dr. Lav Znidarčić je u uvodniku tjednika Nedjelja istaknuo bitne ideje na kojima se temeljilo djelovanje organizacije: vjernost papi i biskupima, djelovanje izvan politike te naglasak na duhovnom životu i apostolskom djelovanju. ${ }^{75}$

O djelovanju križarstva u NDH nalazimo i tekst objavljen $\mathrm{u}$ Nedjelji br. 33, 1944. godine, pod naslovom: „Da se razumijemo“, u kojemu njezin predsjednik dr. Lav Znidarčić iznosi činjenice prema kojima je bilo pokušaja korištenja Križarske organizacije u političke svrhe. Naime, Križarsku organizaciju pokušali su koristiti oni koji nisu pravo shvatili bit križarskog djelovanja. Članak je pisan općenito, ali načelno jasno i bez aluzija, te je bio upozorenje na neprihvatljive stavove i zlouporabe u odnosu na Križarsku organizaciju:

„U našoj Križarskoj organizaciji ima načela, ima temeljnih gledišta koja se nikada ne mogu mijenjati, niti drugačije shvatiti, nego su se uvijek shvaćala. Nikakve nove prilike ne mogu utjecati na naš stav u osnovnim pitanjima križarskog rada! Križarstvo nije organizacija pojedinaca, skupine ili što sličnog, nego je organizacija kojoj je sama Crkva dala ideologiju i smjernice za rad, organizacija koja se u čitavom dosadašnjem radu uvijek vodila smjernicama Papa i Svete Stolice, organizacija, kojoj je dr. Ivan Merz dao jasne poglede na sva aktualna životna pitanja. Stoga je potrebno, da baš danas kada se nalazimo na početku nove radne godine - odgovorimo na neke tvrdnje, za koje smo u posljednje, vrijeme čuli i čitali ih, a to je da se u Križarskoj organizaciji radilo, jer se drugačije nije moglo i to u određenom pravcu i duhu. Duhu, koji je kao takav, nije spadao na Križarsku organizaciju. ${ }^{76}$

Na početku smo naglasili da Križarstvo ima jasna načela. Od osnutka Križarske organizacije je već prošlo skoro 15 godina, a preko 20 godina od početka orlovsko-križarskog rada i možemo utvrditi, da su Križari - makar koliko se oko njih prilike mijenjale i imale utjecaje na križarski rad - uvijek ostali vjerni osnovnim načelima svoga rada i da su baš zato često puta bili krivo suđeni, jer se nisu htjeli odreći svojih načela, načela, koja su karakteristična za hrvatsko Križarstvo. Radili smo i ostali smo vjerni uvijek onim načelima koje

$75 \quad$ Katolički tjednik (1944.), 33, 4.

76 HR - ALZ, fond: Križarstvo, kut. 3, rukopis. 
nam je dala Crkva, formulirao Papa, a na naše prilike prvi primijenio dr. Ivan Merz. Ovaj je naš beskompromisni stav u najvažnijim pitanjima za Križarstvo često značio krize i poteškoće, ali na koncu uvijek pobjedu! Križarstvo je na svom putu ustrajalo i ustrajat će."77

Početkom 1945. godine osjećao se zamor na svim razinama. Vlasti NDH shvatile su da su rat izgubile i da je pitanje mjeseca kada će partizani ući glavni grad. S druge strane, željele su poboljšati odnose s Katoličkom Crkvom i njezinim nadbiskupom Stepincem. Katolička Crkva u Hrvatskoj je bila u strahu od moguće odmazde komunista, što se poslije i obistinilo. Nadbiskup Alojzije Stepinac je u srpnju 1945. raspustio sve organizacije Katoličke akcije, u koje se ubrajala i Križarska organizacija, kako bi članstvo zaštitio od progona, jer su komunisti tražili popise članstva katoličkih organizacija u svrhu progona i uhićenja. Cjelokupni arhiv križarstva, od oko 50 kutija, koji je bio pohranjen u Nadbiskupskom dvoru u Zagrebu, OZNA je zaplijenila u jednoj od premetačina; poslije ga je vjerojatno uništila ili prebacila u Beograd. Započeo je sustavni progon cjelokupnog vodstva Križarske organizacije i njezinih članova."78

\section{ZAKLJUČAK}

Važnost križarstva za Crkvu u Hrvata najbolje je opisao dugogodišnji urednik Glasa Koncila i potom direktor Informativne katoličke agencije (IKA) don Živko Kustić, koji je i sam u mladosti bio član Križarske organizacije na Pagu. U svojoj izjavi u knjizi Hrvatsko križarstvo don Živko Kustić među ostalim kaže:

„Da nije bilo Katoličkog pokreta u kome je Križarstvo najjači ogranak, niti bi se naša domaća Crkva poslije rata tako mogla oprijeti komunizmu, niti bi se bila mogla provesti koncilska obnova. Počnemo li proučavati koja je bila temeljna snaga hrvatskog katolištva u Stepinčevo doba u poslijeratnim strašnim godinama, mislim da bi se moglo dokazati da su snaga Crkve u tim godinama ponajviše bile obitelji koje su bile odgajane u Križarstvu i uopće u Katoličkom pokretu. Preživjeli članovi katoličkih organizacija i njihovi dobro odgojeni potomci, pomagali su svećenike, hranili ih, štitili, hrabrili, također su iz tih redova najviše dolazila nova duhovna zvanja. Tako je naš Katolički pokret - u kojem je Križarstvo bilo i po organizaciji i po redu i po broju lavovski dio - premda toliko prorijeđen ratom i poslijeratnim terorom, postao polazište i izvorište nove crkvene sna-

77 Lav Znidarčić, Da se razumijemo, Nedjelja (1944.) 33, 7.

78 U više je navrata kardinal dr. Franjo Kuharić osobno i preko predsjednika dr. Franje Tuđmana tražio od odgovornih osoba MUP-a RH arhivsku građu koja pripada Križarskoj organizaciji, ali nažalost bez uspjeha. 
ge nakon rata. Crkva u Hrvata svojim klasičnim, starinskim ustrojstvom iz feudalnog doba bez Katoličkog pokreta ne bi ni izdaleka bila tako jaka da se opre komunizmu, da pod njegovim udarcima preživi i da se ponovno probudi, da nije bilo baštine Križarstva i drugih katoličkih organizacija. Bojim se da se to lako zaboravlja. I ne bilo ovakve koncilske obnove da nije bilo Katoličkog pokreta.... Trebalo bi sačuvati, posvijestiti i proučiti silno mnoštvo podataka o djelovanju i sadržajima Križarstva naše mladosti... Još uvijek sam uvjeren da katolički laikat u Hrvatskoj ne može razvijati svoju budućnost zaboravljajući Križarstvo, kao što se ni politički život Hrvatske ni u kojoj stranci ne može graditi bez Starčevića i Radića. Crkva u Hrvata nije bez prošlosti ni bez iskustva. Ne možemo izgraditi suvremeni hrvatski katolički laikat ako bismo prezreli dosad najsnažniju, najplodniju, najorganiziraniju, duhovno i intelektualno najjaču, a na političkom području najnezavisniju formu - Križarstvo."79

\section{ESTABLISHMENT AND WORK OF THE CRUSADERS ORGANIZATION IN CROATIA (1930-1945)}

\section{Summary}

After the dictatorship of King Aleksandar Karađorđević on January 6 and the ban on the Croatian Eagle Alliance, the Crusaders Organization was founded as early as in 1930, based on the principles of the Apostolate of Prayer, i.e. its branch for young people called Croisade Eucharistique, introduced and implemented in Orlovstvo (Eaglehood) by Dr Ivan Merz in 1923.

On February 5, 1936, the Archbishop of Zagreb, Coadjutor Alojzije Stepinac, founded the Diocesan Council of Catholic Action, which operated in accordance with the Rules of Catholic Action. The Crusaders Organization formally operated until July 1945, when the Communists came to power and they would cease their work. They were dissolved personally by Archbishop Alojzije Stepinac in agreement with the leadership of the Catholic Action, to which the Crusaders also belonged.

Keywords: Crusaders, Catholic organizations, leadership, Protulipac, Stepinac, persecutions

79 Božidar Nagy, Hrvatsko križarstvo, Križarska organizacija - Postulatura za beatifikaciju Ivana Merza, Zagreb, 1995., str. 213-214. 